\title{
The Effects of Teachers' Gender, Teaching Experience, and Brain Dominance on Their Teaching Styles
}

\section{Amin Karimnia ${ }^{1 *}$, Nariman Mohammdi ${ }^{2}$}

\footnotetext{
* Correspondence:

aminkarimnia@yahoo.com

1. Fasa Branch, Islamic Azad

University, Iran

2. Marvdasht Branch, Islamic Azad

University, Iran
}

Received: 21 December 2018

Revision: 2 February 2019

Accepted: 20 February 2019

Published online: 20 March 2019

\begin{abstract}
This study investigates the effects of gender, teaching experience, and brain dominance on English teachers' teaching styles. In doing so, 68 English teachers (males and females) were selected from several language institutes in Shiraz, Iran. Considering the degree of teaching experience, the participants were categorized into three groups, namely novices, the moderately experienced, and professionals. Two instruments, including Hemispheric Dominance Test and Teaching Style Questionnaire were used to collect data. Using statistical package for the social science (SPSS) 20, the collected data were analyzed. The results of independent samples t-test revealed that male and female teachers differed significantly in terms of teaching styles, as far as the sub-component "formality" was concerned. Furthermore, the results of multivariate analysis of variance (MANOVA) test indicated that teaching styles in the three groups of teachers significantly differed. However, the analysis of MANOVA regarding the difference between brain dominance and teaching styles did not reveal any significant difference. Some related issues were also discussed.
\end{abstract}

Keywords: brain dominance, gender, teaching styles, teaching experience, hemispheric dominance 


\section{Introduction}

Teaching style has been identified as a significant factor in second language (L2) teaching/learning process. This factor itself can be influenced by a variety of other variables, such as teaching experience, cultural background, and personal preferences (Akbari \& Karimnia, 2017; Karimnia \& Afshari, 2014). The background has evidently emphasized the crucial function that teaching style has in educational contexts, especially as a factor that can affect learners' achievement. Research into the correlation between a multitude of variables affecting L2 teaching style can yield theoretical and practical implications for L2 teachers and researchers.

Teaching experience, for instance, has been used as a criterion for categorizing teachers' styles. Theories of hemispheric dominance suggest that individuals tend to rely on their different brain parts for various cognitive activities, and that such a tendency could influence their performance (e.g. L2 teaching). Similarly, gender has long been regarded as a factor that has an important impact on a teacher's teaching style. These studies, however, are influenced by cultural and contextual determinants, and to gain a thorough image of how teaching styles function in L2 learning, a large magnitude of studies should be complied, especially from societies in which L2 learning is a prevalent practice.

This study seeks to investigate how teaching style is affected by such variables as gender, teaching experience, and brain dominance, in the Iranian English as a Foreign Language (EFL) context, as a dynamic space for L2 research. The study is guided by three major objectives: (a) discover any significant difference between male and female EFL teachers in terms of their teaching styles; (b) find any significant difference between teachers' experience and their teaching styles; and (c) reveal significant difference between EFL teachers' hemispheric preference and their teaching style.

\section{Review of the Literature}

Teaching style is a key factor in the language learning/teaching process (Baradaran, 2016). Teaching style, as explained by Grasha (1996), refers to a teacher's belief, behavior, and needs exhibited in an educational context. In other words, teaching style is the amalgamation of teachers' motivation, personality, attitudes, beliefs, and strategies. Teaching style might be affected by factors such as educational background, teaching and learning experience, cultural background, and personal interests (Felder \& Henriques, 1995; Fischer et al., 2015; Gedzune, 2015; Heimlich \& Norland, 1994; Kazlauskiene, Gaucaite, \& Juodaityte, 2011; Keri, 2002; Nouraey \& Karimnia, 2016; Tavakoli \& Karimnia, 2017). These factors could be identified by observing and studying teachers' behavior.

Experience is one of the major factors that play a role in teachers' teaching style. It is suggested that teachers' experiences regarding successful/unsuccessful teaching performances can help them enhance their performance (Fives, 2010; Kotaman, 2010). A professional experience provides teachers with an opportunity to really think through what they do, and why they do it, and for whom they do it (Ojure \& Sherman, 2001). In another study dealing with the effect of teaching experience on teachers' activities in the classroom, Wolters and Daugherty (2007) found that novice teachers showed significantly lower self-efficacy for teaching practices and classroom organization. Furthermore, experienced teachers were more resilient than novice teachers to adaptation in their beliefs of personal efficacy and practice of tasks of various types (Soodak \& Podell, 1997).

Another important factor that affects styles and strategies is hemispheric dominance. According to Albaili (1996), hemisphericity or hemispheric dominance refers to an individual's tendency to depend on the qualities pertinent to one of brain hemispheres in processing information. Each hemisphere is responsible for a specific function. The left hemisphere, for instance, is generally responsible for the processing of data in logical and sequential ways. On the other hand, the right hemisphere deals with processing the information holistically and nonlinearly (Torrance, 1982).

Moreover, as Willing (1988) points out, the left hemisphere regulates language in terms of analysis and abstraction, whereas the right hemisphere is concerned with more general aspects of language. Research has also shown that most people have a preferred (or dominant) hemisphere, and this hemispheric preference in turn affects their personality, abilities, and teaching/learning style. However, some researchers note that these brains specifications should not be taken as absolute divisions but relative tendencies. Scholars have stated that in most people one cerebral hemisphere may be more active, but this degree of activity varies among individuals (Frank, 1984; Sousa, 2006; Vitale, 1982). Grady (1984) contends that most people exhibit a hemispheric preference for specific functions. At times, a function can be lateralized in the opposite hemisphere or even show mixed dominance. According to Sousa (2006), the 
functions are hardly limited to only one hemisphere, because it is possible for both of the hemispheres to process the same function.

Investigating the impact of teaching experience and gender on teaching styles, Baleghizadeh and Shakouri (2014) selected 87 English for Specific Purposes (ESP) instructors. The participants filled in the Teaching Styles Inventory. An independent samples t-test analysis and a one-way Analysis of Variance (ANOVA) were used to evaluate the predicting power of gender and teaching experience in identifying ESP instructors' teaching styles. They found no significant relationship between teaching experience and teaching styles. Moreover, the relationship between teacher gender and teaching style was not significant.

In a similar study, Faruji (2012) examined the dominant teaching style used by teachers in private language institutes in Iran based on Grasha's taxonomy. Grasha (1996) identified five teaching styles in his taxonomy as: Expert, Formal Authority, Personal Model, Facilitator, and Delegator Styles. Faruji (2012) found that male teachers used the formal authority style more than female teachers. Moreover, younger teachers were more interested in using formal authority style. Novice teachers also used the formal authority style more than professional teachers. The researcher concluded that there was a relationship between teachers' teaching style and their gender, age, and teaching experience. Formal authority style was employed mostly by male, younger, and low experienced teachers.

Aliakbari and Soltani (2009) studied the impact of gender and teaching experience on the teaching styles implemented by teachers in the classroom. The findings of the study revealed that male and female Iranian EFL teachers showed significant differences in their teaching styles. Male and female teachers, for example, differed in terms of extroverting, sensing, and feeling styles of teaching. With respect to the relationship between teaching experience and teaching styles, the study showed a negative relationship with sensing style and there was a positive relationship with thinking style of teaching.

Brew (2002) and Karimnia (2003) also pointed out that teaching style varies depending on a teacher's age, gender, education level, and learning style. According to Brew's (2002) study, female teachers and novices rely on more learner-centered styles of teaching. Moreover, Gorrell and Dharmadasa (1994) stated that although pre-service teachers employed new methods of teaching in the classroom, experienced teachers put emphasis on classroom management and organization of instruction and impacts of these factors on students.

For example, Sousa (2006) and Vitale (1982) observed that left and right hemispheres had distinctive cognitive functions. On this account, every individual has two unique ways of processing information. For example, it is generally accepted that the left hemisphere is responsible for auditory, verbal, analytical, logical, abstract, convergent, and deductive functions. On the other hand, the right hemisphere is responsible for visual, motoric (tactile/kinesthetic), non-verbal, intuitive, creative, divergent, concrete, musical, spatial, holistic, and inductive functions (Kane \& Kane, 1979).

Reviewing the literature, Torrance (1982) points out that hemisphericity is the propensity of a person to depend more on one cerebral hemisphere in processing information. Saleh (2001) reviewed the literature and suggested that in processing the information, people tend to rely on the left hemisphere or the right hemisphere or the combination of both. Further, research has indicated that the two hemispheres, to some degree, are lateralized or dominant for different functions (Halpern, 2013). Despite this background, the concept of hemisphericity in teaching style has not been thoroughly explored. The purpose of this study is to investigate teaching styles in association with gender, teaching experience, and brain dominance in an L2 teaching/learning style.

\subsection{Research Questions}

This study was guided by three major questions:

1. Is there any significant difference between male and female EFL teachers in terms of their teaching styles?

2. Is there any significant difference between teachers' experience (novices, the moderately experienced, and professionals) and their teaching style?

3. Is there any significant difference between EFL teachers' hemispheric preference and their teaching style?

\section{Methodology}

3.1 Participants 
The participants of this study were 68 Iranian EFL teachers teaching at several language institutes in Shiraz, Fars province, Iran. The selection of the participants was based on purposive sampling as the teachers' experience was an important factor in selecting them. More specifically, teachers with different levels of teaching experience were selected, ranging from novices to professionals. Out of the total number of teachers, there were 31 males and 37 females. The participants' age ranged from 21 to 39 and their teaching experience also ranged from 1 to 11 years. Table 1 presents the participants' information.

Table 1. Participants' information regarding their gender, experience, and hemisphere preference

\begin{tabular}{llll}
\hline & Teachers' information & Frequency \& Percentage & Total \\
\hline Gender & Male & $31 \& \% 45.58$ & 68 \\
& Female & $37 \& \quad 54.41$ & \\
\hline Teaching Experience & Novice & $22 \& 32.35$ & \\
& Moderately experienced & $30 \& 44.11$ & \\
& Professional & $16 \& 23.52$ & 68 \\
\hline Brain dominance & Left hemisphere & $37 \& 54.41$ & \\
& Right hemisphere & $25 \& 36.76$ & \\
& Whole brain & $6 \& 8.82$ & \\
\hline
\end{tabular}

\subsection{Instruments}

Two questionnaires were used to investigate the effect of teachers' gender, teaching experience, and brain dominance on their teaching styles. The Hemispheric Dominance Test (HDT) was employed to evaluate the students' brain dominance patterns. A Teaching Style Questionnaire (TSQ) was also used to investigate teachers' teaching styles.

\subsubsection{Hemispheric dominance test (HDT)}

Hemispheric Dominance Test (HDT) was employed to study participants' hemisphere preferences. This 39-item questionnaire is a modification of Davis, Nur, and Ruru's (1994) Brain Dominance Inventory with three multiplechoice alternatives $(\mathrm{a}, \mathrm{b}, \mathrm{c})$ for each item. The questionnaire helped classify left/right brain dominance and whole brainers. In order to categorize participants into groups, first, the values of "a", "b" and "c" items in the questionnaire were counted separately. Next, the sum of all "a" scores was subtracted from the sum of "b" scores. Finally, in cases where "c" values were 17 or greater, the "b" minus "a" scores were divided by three, and rounded up to the nearest number. Ultimately, the participants who received negative scores were categorized in the left-brain dominant group. Those with positive scores were considered to be right-brain dominant, and those who scored zero on the scale were classified as whole brainers.

\subsubsection{Teaching style questionnaire (TSQ)}

Using the Teaching Style Questionnaire (TSQ) designed by Evans (2004), the teachers' teaching styles were scrutinized. This likert-type questionnaire included 34 items scored on a range of 1 to 5, ranging from "strongly agree" to "strongly disagree." Through TSQ, holistic-analytic tendencies were measured. Four styles were measured via this questionnaire: (a) "structure" (a style of teaching that emphasizes thoroughness, planning, assessment, and organization); (b) "sociability" (a style of teaching that focuses on being outgoing, personal, individualistic, and social); (c) "formality" (a style of teaching that underscores rules, procedures, discipline, and feedback); (d) and "caution" (a style of teaching that focuses on rationality and reflectivity). The reliability estimate for the teaching style scale was calculated using the Cronbach's alpha formula and was found to be 0.76 . 


\subsection{Data Collection Procedure}

In order to enhance the validity of the responses, the participants of this study were informed about the purpose of the study. For the ease of data collection, each participant received a code to write down on the questionnaires, to identify each participant. The data were initially collected through the administration of HDT. The participants were asked to complete the test in thirty minutes in order to decide their hemispheric preferences. After the completion of the first questionnaire, TSQ was administered. The participants were, then, requested to complete the questionnaire within thirty minutes.

\subsection{Data Analysis Procedure}

The collected data were fed into SPSS 20. To answer the first research question, independent samples t-test was employed. For the second research question, a test of MANOVA was conducted to investigate the difference between the three levels of teachers' experience and teaching styles. For the last research question of the study, a test of MANOVA was conducted.

\section{Findings and Results}

\subsection{The Effect of Gender on Teachers' Teaching Style Preferences}

An independent samples t-test was run to investigate whether male and female teachers differed in terms of their teaching styles. Tables 2 and 3 present the results of the analysis.

Table 2. Descriptive statistics of the gender and teaching style subscales

\begin{tabular}{llllll}
\hline & Gender & $\mathrm{N}$ & $\mathrm{M}$ & $\mathrm{SD}$ & Std. Error Mean \\
\hline Structure & male & 31 & 16.90 & 1.85 & .33233 \\
& female & 37 & 17.51 & 1.16 & .19227 \\
\hline Sociability & male & 31 & 23.25 & 2.54 & .45665 \\
& female & 37 & 24.21 & 1.65 & .27162 \\
\hline Formality & male & 31 & 16.22 & 2.64 & .47453 \\
& female & 37 & 14.72 & 2.95 & .48653 \\
\hline Caution & male & 31 & 11.90 & 1.37 & .24694 \\
& female & 37 & 11.75 & 1.23 & .20285 \\
\hline
\end{tabular}

Table 2 shows the mean scores and standard deviations of the teachers' responses on each of the subscales of the teaching style questionnaire. As Table 2 specifies, female teachers scored higher on two subscales of the questionnaire, namely "structure" (males: $\mathrm{M}=16.90, \mathrm{SD}=1.85$; females: $\mathrm{M}=17.51, \mathrm{SD}=1.16$ ) and "sociability" (males: $\mathrm{M}=23.25$, $\mathrm{SD}=2.54$; females: $\mathrm{M}=24.21, \mathrm{SD}=1.65$ ). On the other hand, male teachers scored higher on the other two subscales of the questionnaire, "formality" (males: $\mathrm{M}=16.22, \mathrm{SD}=2.64$; females: $\mathrm{M}=14.72, \mathrm{SD}=2.95$ ) and "caution" (males: $\mathrm{M}=11.90, \mathrm{SD}=1.37$, females: $\mathrm{M}=11.75, \mathrm{SD}=1.23$ ). 
Table 3. Results of Independent Samples t-test of male and female teachers' teaching style

\begin{tabular}{lllll}
\hline & $\mathrm{F}$ & $\mathrm{t}$ & $\mathrm{df}$ & Sig. (2-tailed) \\
\hline Structure & 4.89 & -1.65 & 66 & .103 \\
Sociability & 10.92 & -1.87 & 66 & .066 \\
Formality & 1.17 & 2.17 & 66 & .033 \\
Caution & .403 & .463 & 66 & .645 \\
\hline
\end{tabular}

As Table 3 shows, male and female teachers' teaching style significantly differed in terms of "formality" as a style of teaching $(\mathrm{t}(66)=2.17, \mathrm{p}=.033)$. Regarding the three other teaching styles, there was no significant difference between male and female teachers as the significance values were greater than .05 .

\subsection{The Effect of Teaching Experience on Teachers' Teaching Styles}

Using MANOVA, the possible difference between teachers' teaching styles across the three teaching experience group was measured. Table 4 illustrates the results of the analysis.

Table 4. Multivariate tests for the effect of teaching experience on teaching styles

\begin{tabular}{lllllll}
\hline Effect & value & F & hypothesis df & Error df & Sig. & D \\
\hline Wilks' Lambda & .776 & 2.098 & 8.000 & 124.000 & .041 & .119 \\
\hline
\end{tabular}

Table 4 shows that there was a statistically significant difference between the three groups of teaching experience $(\mathrm{F}$ $=2.098, \mathrm{p}=.041$; Wilks' Lambda $=.776$; partial eta squared= .119). However, this test could not help reveal which subscale was different in the three groups. Therefore, tests of between-subjects effects were run. Table 5 shows the result of test of between-subjects effects.

Table 5. The results of test of Between-Subjects effects

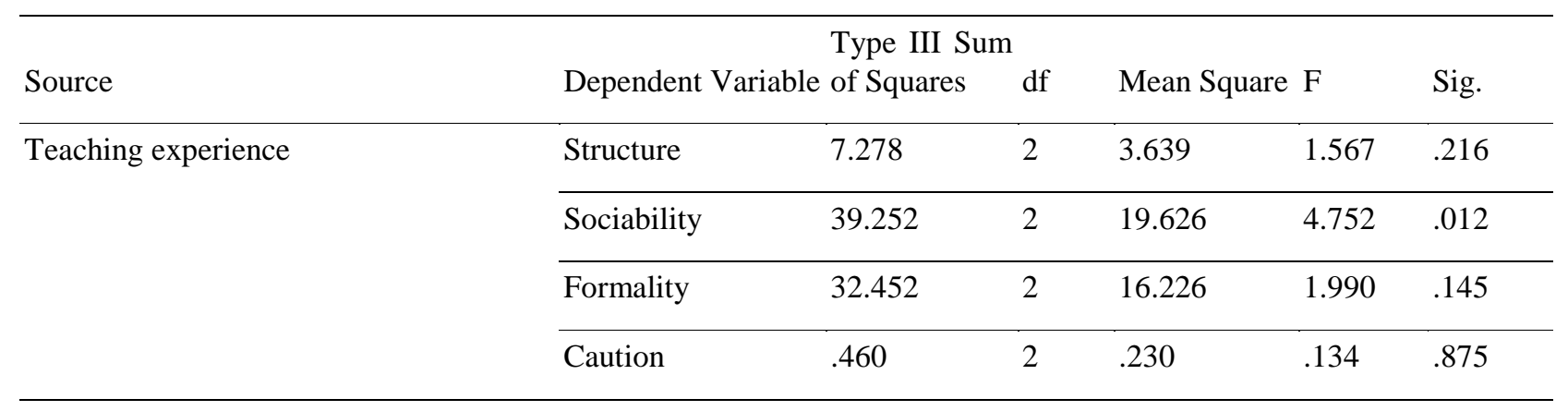

As Table 5 shows, sociability style marked the difference $(\mathrm{p}=.012)$. In other words, the three groups of teachers differed significantly in terms of sociability teaching style. In order to detect the group marking the difference, Scheffe's test was conducted. Table 6 lists the result of the analysis. 
Table 6. Scheffe's test of the three levels of teaching experience and sociability teaching styles

\begin{tabular}{lllrr}
\hline Teaching experience (I) & Teaching experience $(\mathrm{J})$ & Mean Difference (I-J) & SD & Sig. \\
\hline Novice & Moderately experienced & $-1.65152^{*}$ & .57042 & .019 \\
\cline { 2 - 5 } & Professional & -1.56818 & .66771 & .071 \\
\hline Moderately experienced & Novice & $1.65152^{*}$ & .57042 & .019 \\
\cline { 2 - 5 } & Professional & .08333 & .62911 & .991 \\
\hline Professional & Novice & 1.56818 & .66771 & .071 \\
\cline { 2 - 5 } & Moderately experienced & -.08333 & .62911 & .991 \\
\hline
\end{tabular}

Table 6 shows the results of post-hoc comparisons using Scheffe's test. As indicated by the data, novice teachers' teaching style significantly differed from moderately experienced teachers' teaching style in terms of "sociability" as a subscale.

\subsection{The Effect of Brain Dominance on Teaching Style}

To investigate the possible effect of brain dominance on teaching style, the MANOVA test was run. Table 7 presents the results of the analysis.

Table 7. Multivariate tests for the effect of hemisphere dominance on different teaching styles

\begin{tabular}{lccccc}
\hline Effect & value & F & hypothesis df & Error df & Sig. \\
\hline Wilks' Lambda & .888 & .984 & 8.000 & 124.000 & .058 \\
\hline
\end{tabular}

As Table 7 shows, there was no statistically significant difference between left, right, and whole brain dominance teachers regarding their teaching styles, as the significance value was greater than $0.5(\mathrm{p}=.058)$.

\section{Discussion}

The first research question of the study sought to investigate any possible difference between male and female teachers in terms of their teaching styles. The results of the study revealed that there was a significant difference between teachers' gender and their teaching styles. They also differed in terms of "formality" as a teaching style. The findings were in line with Brew's (2002) observation who found a difference between male and female teachers in terms of the teaching styles they employed in classrooms. The findings were also compatible with those of Rahimi and Asadollahi (2012) and Aliakbari and Soltani (2009), who discovered the significant role of gender in teaching style preferences.

Yet, in contrast to the findings of the present study, Baleghizadeh and Shakouri (2014), in a study on the effect of gender on Iranian ESP instructors' teaching styles, observed no significant relationship between gender and teaching styles. The finding could be justified by the context of the study, that is, educational discourse. In this particular discourse, both female and male in their roles as teachers need to be both independent, competitive, assertive, compassionate, and understanding, etc. In addition, students rejected gender as a salient factor in teacher-student relations, and emphasized that individual teaching ability has the salient effect (Badjanova, Pipere, \& Ilisko, 2017).

The second research question addressed the possible impact of teaching experience on teaching styles. According to the findings of the study, there was a significant difference between the three groups of teaching experience with respect to their teaching styles. More specifically, novice teachers differed from moderately experienced teachers in terms of the "sociability" teaching style. Several studies have confirmed the impact of teaching experience on classroom teachers' styles. For instance, Wolters and Daugherty (2007) and Soodak and Podell (1997) stated that teachers' experience was an effective factor that influenced the type of style they employed during the course of teaching. They specifically mentioned that the approaches and styles adopted by novice teachers were different from those preferred by more experienced teachers. 
The literature, of course, involved studies with relatively conflicting results. For example, Gorrell and Dharmadasa (1994) indicated that although pre-service teachers preferred practicing new methods of instruction, experienced teachers focused more on classroom management and organization of instruction and their effects on students. Despite this observation, in contrast to the findings of the present study, Baleghizadeh and Shakouri (2014) and Rahimi and Asadollahi (2012) found no significant relationship between teaching experience and teaching styles.

The results of this study concerning the impact of brain dominance on teaching styles revealed no significant difference. The results of the study were in clash with those of James (2007) and Gurian and Stevens (2004) who observed that brain hemispheres were responsible for specific tasks and preferred specific styles and strategies.

\section{Conclusion}

This study revealed the effect of three factors, hemispheric dominance, teaching experience, and gender on teachers' teaching styles. According to the findings of the study, male and female teachers differed only in one category of teaching style and displayed consistent ideas as far as the rest of the categories were concerned. The only category that differed across the two genders was "formality", which is the style of teaching that focuses on rules, procedure, discipline, and feedback. Furthermore, the study found that novice teachers differed from moderately experienced teachers regarding the "sociability" category of teaching style. Those following the sociability style tended to be outgoing, personal, individualistic, and social. According to this finding, sociability was found to be a matter of experience; in other words, due to a lack of professional experience in the field of teaching, novice teachers approached the classroom with a style that differed from their more experienced colleagues. The result of the study regarding the effect of brain hemispheric dominance on teachers' teaching style revealed no significant difference. It was found that left, right, and whole brain teachers were not significantly different in terms of the type of teaching style they used in the classroom. One possible reason for this tendency might involve teachers' attempt to adapt their teaching styles to their learners, instead of following their individual characteristics. In this study, the teachers' characteristics did not reveal any significant effect on their teaching styles in general. This observation might point to the fact that learners' characteristics and learning styles were so important for the teachers that they followed the style and strategies that best suited the needs of their students.

\section{References}

Akbari, E., \& Karimnia, A. (2017). Learning style preferences in male and female professional translators. The Journal of English Language Pedagogy and Practice, 10(20), 1-16.

Albaili, M. A. (1996). Inferred hemispheric style and problem-solving performance. Perceptual and motor skills, 83(2), 427-434. https://journals.sagepub.com/doi/10.2466/pms.1996.83.2.427

Aliakbari, M., \& Soltani, N. (2009). Variation of learning styles among Iranian EFL learners: Effects of culture, language background and gender. Proceedings of the 16th Conference of Pan-Pacific Association of Applied Linguistics. Centre for Enhancing English Learning and Teaching: Hong Kong. Retrieved from www.paaljapan.org/conference2011/mate/CFP_16thPAAL.pdf

Badjanova, J., Pipere, A., \& Ilisko, D. (2017). Gender identity of students and teachers: Implications for a sustainable future. Journal of Teacher Education for Sustainability, 19(2), 138-153. doi: 10.1515/jtes-2017-0019

Baleghizadeh, S., \& Shakouri, M. (2014). The effect of gender and teaching experience on Iranian ESP instructors' teaching styles. Journal of Education and Human Development, 3(2), 979-989. http://jehdnet.com/journals/jehd/Vol_3_No_2_June_2014/59.pdf

Baradaran, A. (2016). The Relationship between teaching styles and autonomy among Iranian female EFL teachers, teaching at advanced levels. English Language Teaching, 9(3), 223. http://www.ccsenet.org/journal/index.php/elt/article/view/57538

Brew, C. R. (2002). Kolb's learning style instrument: Sensitive to gender. Educational and Psychological Measurement, 62(2), 373-390. https://journals.sagepub.com/doi/pdf/10.1177/0013164402062002011

Davis, E. C., Nur, H., \& Ruru, S. A. A. (1994). Helping teachers and students understand learning styles. English Teaching Forum, 32(3), 12-38. 
Evans, C. (2004). Exploring the relationship between cognitive style and teaching style. Educational Psychology, 24(4), 509-530. https://www.tandfonline.com/doi/abs/10.1080/0144341042000228870

Faruji, L. F. (2012). Teachers' teaching styles at English language institutes in Iran. International Journal of Social $\begin{array}{llll}\text { Sciences } \quad \text { and } \quad \text { Education, } & 364-373 .\end{array}$ http://ijsse.com/sites/default/files/issues/2012/volume\%202\%20issue\%201\%20Jan\%202012/paper\%2028/pa per-28.pdf

Felder, R. M., \& Henriques, E. R. (1995). Learning and teaching styles in foreign and second language education. Foreign Language Annals, 28(1) 21-31. https://onlinelibrary.wiley.com/doi/abs/10.1111/j.19449720.1995.tb00767.x

Fischer, D., Aubrecht, E. L., Bruck, M., Ditges, L., Gathen, L., Jahns, M., \& Wellmann, C. (2015). UN global action programme and education for sustainable development: A critical appraisal of the evidence base. Discourse and Communication for Sustainable Education, 6(1), 5-20. doi: 10.1515/dcse-2015-0001

Fives, H. (2010). Examining the factor structure of the teachers' sense of efficacy scale. Experimental Education, 78(1), 118-134. https://www.montclair.edu/profilepages/media/1391/user/Fives\&Buehl_2010_JXE.pdf

Frank, M. I. (1984). A child's brain: The impact of advanced research on cognitive and social behaviors (Vol. 16, No. 1-2). NY: Psychology Press.

Gedzune, G. (2015). Awakening pre-service teachers to children's social exclusion in the classroom. Discourse and Communication for Sustainable $\quad$ Education, $\quad 6(1), \quad 95-109$. https://content.sciendo.com/view/journals/dcse/6/1/article-p95.xml

Gorrell, J., \& Dharmadasa, K. H. (1994). Perceived efficacy of pre-service and in-service Sri Lankan teachers. International Education, 24(1), 23.

Grady, M. P. (1984). Teaching and brain research: Guidelines for the classroom. London: Longman.

Grasha, A. F. (1996). Teaching with style: A practical guide to enhance learning by understanding learning and teaching style. College Teaching, 48, 1-12. https://www.amazon.com/Teaching-Style-Practical-EnhancingUnderstanding/dp/0964507110

Gurian, M., \& Stevens, K. (2004). With boys and girls in mind. Educational Leadership, 62(3), 21-26. https://eric.ed.gov/?id=EJ725955

Halpern, D. F. (2013). Sex differences in cognitive abilities. NY: Psychology Press.

Heimlich, J. E., \& Norland, E. (1994). Developing teaching style in adult education. The Jossey-Bass Higher and Adult Education Series. Jossey-Bass, Publishers, 350 Sansome Street, San Francisco, CA 94104.

James, A. (2007). Teaching the male brain: How boys think, feel, and learn in school. Thousand Oaks, CA: Corwin Press.

Kane, N., \& Kane, M. (1979). Comparison of right \& left hemisphere functions. Gifted Child Quarterly, 23(1), 15767. https://eric.ed.gov/?id=EJ206439

Karimnia, A. (2003). The effect of speaker's and listener's gender on listening comprehension. Indian Journal of applied linguistics, 29(1), 99-107. https://eric.ed.gov/?id=EJ662938

Karimnia. A., \& Afshari. S. (2014). The effect of translators' learning style on translation quality of expressive texts. Khazar Journal of Humanities and Social Sciences, 17(1), 42-49.

Kazlauskiene, A., Gaucaite, R., \& Juodaityte, A. (2011). Informing society about preschool education and educational support in the context of sustainable development. Discourse and Communication for Sustainable Education, 2(1), 32-45. https://content.sciendo.com/abstract/journals/dcse/2/1/article-p32.xml

Keri, G. (2002). Degrees of congruence between instructor and student styles regarding student satisfaction. Radical Pedagogy, 4(1), 42-50. 
Kotaman, H. (2010). Turkish early childhood educators' sense of teacher efficacy. Electronic Journal of Research in Educational Psychology, 8(2), 603-616. https://www.redalyc.org/html/2931/293122002008/

Nouraey, P., \& Karimnia, A. (2016). The impact of rhythm and gender on spelling output of Iranian EFL learners: A cross-sectional study. Khazar Journal of Humanities and Social Sciences, 19(2), 53-63. http://jhsskhazar.org/wp-content/uploads/2016/05/R302.19.2016.revised_3-1.pdf

Ojure, L., \& Sherman, T. (2001). Learning styles. Education Week American Education's Newspaper of Record, November Issue.

Rahimi, M., \& Asadollahi, F. (2012). Teaching styles of Iranian EFL teachers: Do gender, age, and experience make a difference? International Journal of English Linguistics, 2(2), 157-164. doi:10.5539/ijel.v2n2p157

Saleh, A. (2001). Brain hemisphericity and academic majors: A correlation study. College Student Journal, 35(2), 193. https://www.questia.com/library/journal/1G1-77399626/brain-hemisphericity-and-academic-majors-acorrelation

Soodak, L. C., \& Podell, D. M. (1997). Efficacy and experience: Perceptions of efficacy among pre-service and practicing teachers. Journal of Research and Development in Education, 30(4), 214-221. https://eric.ed.gov/?id=EJ553068

Sousa, D. A. (2006). How the brain learns: A classroom teacher's guide. Thousand Oaks, CA: Corwin Press.

Tavakoli, M., \& Karimnia, A. (2017). Dominant and gender-specific tendencies in the use of discourse markers: Insights from EFL learners. World Journal of English Language, 7(2), 1-9. http://www.sciedupress.com/journal/index.php/wjel/article/view/11603

Torrance, E. P. (1982). Hemisphericity and creative functioning. Journal of Research \& Development in Education, 15(3), 29-37. https://eric.ed.gov/?id=EJ262568

Vitale, B. M. (1982). Unicorns are real: A right-brained approach to learning. Rolling Hills Estates, CA: Jalmar Press.

Willing, K. (1988). Learning styles in adult migrant education. Adelaide, South Australia: National Curriculum Research Council.

Wolters, C. A., \& Daugherty, S. G. (2007). Goal structures and teachers' sense of efficacy: Their relation and association to teaching experience and academic level. Journal of Educational Psychology, 99(1), 181. https://pdfs.semanticscholar.org/0232/6129b6bbddbe9034ee701fc65fde89be698c.pdf 